\title{
“The Laughing Rolling Stock of the State": The Ames \& College Railway, 1902-1907
}

\section{DOUGLAS BigGS}

STREET RAILWAYS came in many forms across the Midwest in the late nineteenth and early twentieth centuries. Many, such as the Citizens Street Railway Co. in Danville, Illinois, and the St. Paul Railway Company in St. Paul, Minnesota, were horse-drawn operations. ${ }^{1}$ Others, such as the Chicago Passenger Railway and the West Chicago Railroad Co., were cable car lines. Iowa had a wide variety of urban and rural transportation systems. Although tiny Red Oak built and maintained a horse-and-mule-drawn street railway, steam proved to be the most viable mode of power for most street railways across the state. ${ }^{2}$ But these midwestern

A version of this article was delivered at the 58th Missouri Valley History Conference at Omaha, Nebraska, in March 2015. I appreciate the comments on my paper by Professor Harl Dalstrom and the audience. I also wish to thank the Special Collections staff at Iowa State University, especially Becky Jordan, for help as I researched this article. Gloria Betcher of the English Department at Iowa State University discussed points large and small with me at length. All of their comments helped me improve the article.

1. James J. Buckley, “The Street Railways of Danville, Illinois,” ed. H. George Friedman Jr., http:/ / friedman.cs.illinois.edu/danville/Buckley.htm; Stephen A. Kieffer, Transit and the Twins (Minneapolis, 1958).

2. Greg Borzo, Chicago Cable Cars (Chicago, 2012); Richard Prosser, "The Motor Train in Iowa," Annals of Iowa 42 (1975), 557-63. The horse-drawn street railway in Red Oak operated from 1881 until 1902, when the track was torn up to pave the city streets. W. W. Merritt, A History of the County of Montgomery from the Earliest Days to 1906 (Red Oak, 1906), 292-93.

THE ANNALS OF IOWA 75 (Spring 2016). (C) State Historical Society of Iowa, 2016. 
street railways soon encountered problems: horse cars got stuck in the deep snows of St. Paul; steam engines were noisy, dirty, and often an unsightly blot on the city streetscape. Although the cable car system in Chicago could be counted among the world's largest in the 1880s, it was too slow to meet the demands of its passengers. From about 1880 to 1920, street railways across the Midwest turned to electricity to provide clean, efficient, and reliable power.

The street railway in the city of Ames, with its growing state college, was no exception to this trend. By the first years of the twentieth century, the locally owned and operated Ames \& College Railway, popularly known to contemporaries as the Motor Line and the "Dinkey," found itself unable to meet the transportation needs of the town of Ames and Iowa State College (ISC). The A\&C's directors had originally intended to build an electric service to unite the town and the college, but the board found it too expensive a venture, so when the college would not accept the company's proposal for a horse-drawn line, the A\&C, like other railroads, had to adopt steam as the only mode of propulsion it could afford. ${ }^{3}$ Thus, the A\&C began life in 1891 as a singletrack, steam dummy passenger and freight service between the town and the college two miles to the west. ${ }^{4}$ The little railroad represented the only reliable transit route between Ames and the campus: the only alternative to the Motor Line was an undrained dirt track/wagon road known as Boone Street, which ran through the flood plain of Squaw Creek. ${ }^{5}$

3. Trustee William McElroy from Newton served on the board of trustees committee that gave the A \& C its first contract in 1891. Looking back on the committee's decision 14 years later, he wrote that concerns were expressed that "under conditions then existing [i.e., in 1891], [building the railway] involved the expenditure of considerable money by the company, with much uncertainty regarding the wisdom of the investment, viewed from the financial standpoint." Minutes, ISC Board of Trustees, Book C, July 1903-January 1907, 9/29/1905, pp. 369-72, Special Collections, Iowa State University Library, Ames.

4. For discussions of the A\&C and its impact on the history of Ames, see William Orson Payne, History of Story County: A Record of Settlement, Organization, Progress and Achievement, 2 vols. (Chicago, 1911), 1:486-87; Gladys Meades, At the Squaw and Skunk (Ames, 1955), 142; Farwell Brown, Ames: A Ride through Town on the Dinkey (Charleston, SC, 2001); and Douglas Biggs, "Forging a Community with Rails: Ames, Iowa Agricultural College, and the Ames \& College Railway, 1891-1896," Annals of Iowa 71 (2012), 211-40.

5. The Iowa legislature approved the building of this highway to run to the south of the college farm on April 18, 1864. Acts of Iowa, 1864, 69-71. 


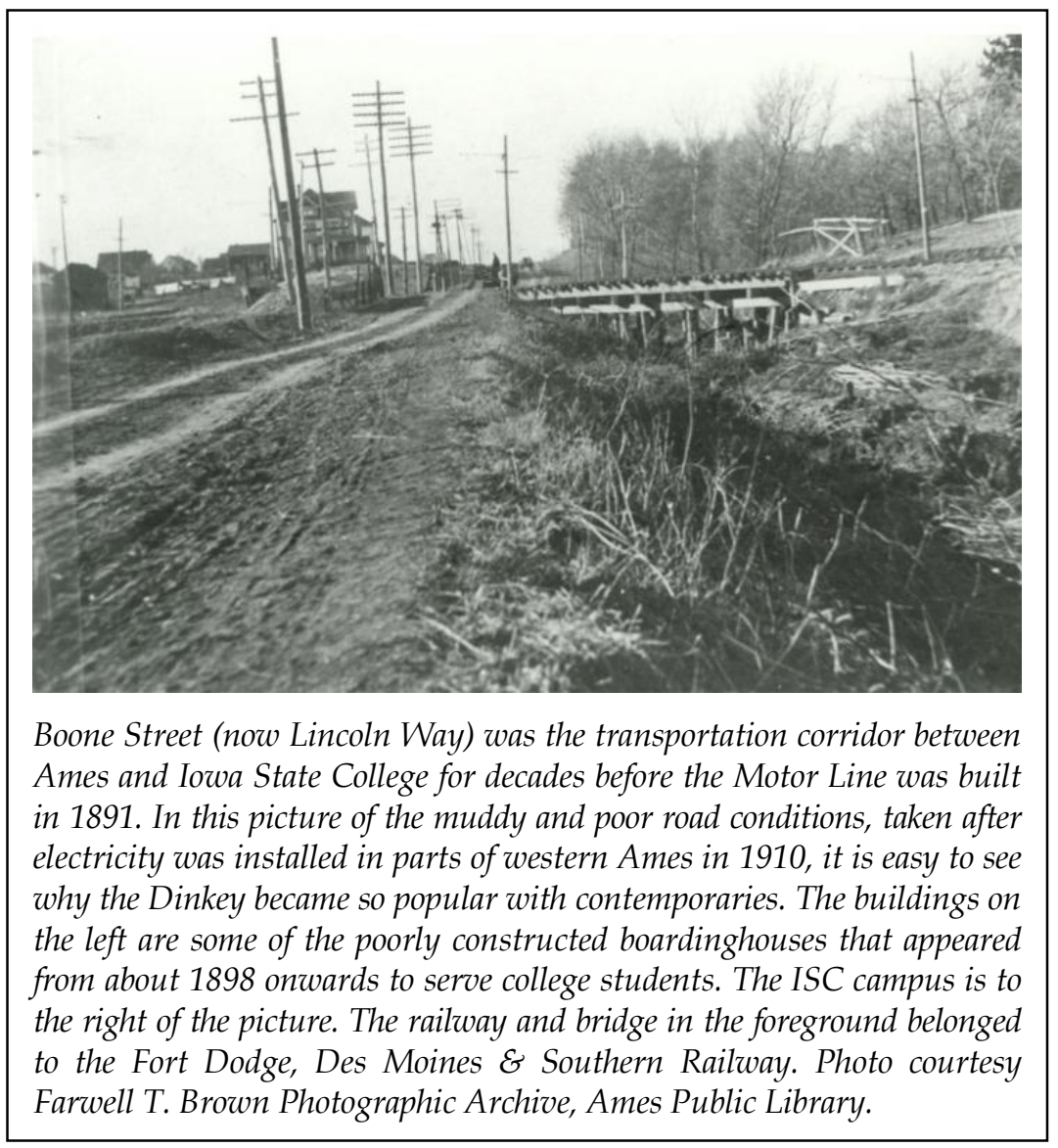

Throughout the 1890s Ames citizens and ISC students loved to ride what they called the Dinkey, with all of its attendant excitement, and they saw the "fussy, stuffy, little motor" as their "pet Motor Line." 6 The little train was almost universally described as "the pride of the community." 7 Yet, by the final months

6. Meades, Squaw and Skunk, 142. Roger Grant argues that this feeling of excitement was nearly universal across small towns and rural areas in the Midwest. H. Roger Grant, Twilight Rails: The Final Era of Railroad Building in the Midwest (Minneapolis, 2010), 1-4.

7. The pride in and civic ownership of the $A \& C$ are perhaps best demonstrated by articles in contemporary publications such as the Ames Times, 1/5/1893, and the ISC Bomb, 1895, pp. 121-22. It is also clear that Ames citizens and ISC students reflected their pride in the Motor Line to visitors from across the state; 
of 1902, the same vox populi that had lionized the railroad since its inception seemed to find nothing but fault with it, and vented increasing levels of frustration at the little train. By 1904, contemporaries described the Dinkey as a "dilapidated" enterprise, where passengers sat in "dirty tram car[s]" pulled "in the wake of an engine that beggars description." The track had "more jogs in it than the road to success," and some considered "the junk pile" the only fitting mausoleum for the train. In fact, at least one newcomer to the community, Fredrica Shattuk, who took up her duties on the faculty of ISC's Speech Department in 1907, was not quite sure what the Dinkey even was and thought it "a very curious little contraption." By 1907, the same railroad that less than a decade before had been described as the "pride of the community" had become the "laughing rolling stock of the state." 8

How could such a reversal of fortune happen in such a brief period of time to such a successful and beloved local business? An investigation into the last five years of the $A \& C$ reveals three main causes for the railroad's demise. First, although in the years following the autumn of 1902 the Ames \& College Railway had transformed Ames and ISC into one community, the railroad's infrastructure had become so stressed that it could not bear the weight of the service the community demanded. Between 1902 and 1907, as the A\&C's physical plant degraded, students and townspeople alike noted employee carelessness and overcrowding that resulted in accidents of increasing severity. The second main cause for the A\&C's demise was simply a lack of funds to make sorely needed upgrades. An inability to charge the legally allowed passenger fare, combined with the company's

some of their observations found their way into far-flung newspapers such as the Cedar Falls Gazette, 4/5/1895.

8. ISC Student, 3/5/1904; ISC Bomb, 1908 (the 1908 edition did not have page numbers); Jenny Barker Devine, "'A Very Curious Little Contraption': Getting to and from Campus in the Early Years," in Traditions and Transformations: A Sesquicentennial History of Iowa State University, ed. Dorothy Schwieder and Gretchen Van Houten (Ames, 2007), 5-6; Ames Intelligencer, 12/5/1907. The horse-and-mule-car street railway in Red Oak faced a similar type of public abuse so that by 1900, "the mule car system became more or less of a standing joke among traveling men throughout the Western country." Merritt, History of Montgomery County, 293. 
focus on community service instead of profit, meant that the railroad did not possess the resources to make the necessary change from steam to electricity that would have ensured the continued success of the company. In spite of these businesses practices, the A\&C was able to limp along with its outmoded and outdated equipment until it sold out because of the third cause of its demise: the changing nature of its relationship with its most important customer, Iowa State College. The increasing number of students and a change in college leadership in 1902 led the new president and the trustees to conclude that ISC needed "nothing short of a replanning-a new campus" that required a different transportation system than the dilapidated one they had. ${ }^{9}$

BY THE AUTUMN of 1902, Iowa State's enrollment had reached 1,272 , more than enough students to fill the 228 dormitory rooms that the college possessed. ${ }^{10}$ Before his death in August 1902, President William Beardshear had encouraged entrepreneurs to construct boardinghouses on the southern fringe of campus and within the city limits. No fewer than five boardinghouses had been built by the end of 1899, but they were hastily erected, poorly built, and soon became overcrowded. ${ }^{11}$ These establishments, which were certainly convenient to the campus, lacked city water, sewer, and electric services, shortcomings that made the houses unhealthy. After an outbreak of typhoid fever in 1906 in a boardinghouse called The Colonnades, students found more attractive housing options downtown, where all city servicesand a nightlife - were readily available. President Beardshear's successor, Albert Storms, decided in 1904 to allow Greek Letter fraternities and sororities, which had been banned from campus

9. Earle Ross, A History of the Iowa State College of Agriculture and Mechanic Arts (Ames, 1942), 243. As part of this replanning, the trustees demanded that the A \& C upgrade its line to "electricity, gasoline or some other motive power not accompanied by smoke." Minutes, ISC Board of Trustees, Book C, July 1903January 1907, 9/29/1905, pp. 369-72.

10. The figure of 228 beds is drawn from J. C. Schilletter, "The First 100 Years of Residential Housing at Iowa State University, 1868-1968," Internal Publication, Iowa State University, 1970, Special Collections, ISU Library, p. 54.

11. Ibid., 66. For a discussion of these five boardinghouses, see President's Report, 10/5/ 1899, p. 5, William Miller Beardshear Papers, folder 1/9, box 1, RS 2/5, Special Collections, ISU Library. 
since 1891, to colonize at ISC. ${ }^{12}$ Some of these Greek houses were interspersed with the boardinghouses south of campus, but a number of Greek Letter houses colonized downtown and, like their non-Greek compatriots, relied on transportation that the Dinkey provided.

The housing crisis and the sudden rise in the number of students living in town meant a significant increase in ridership for the A\&C. In the 1902-3 fiscal year, the little train carried 177,560 passengers, 35 percent more than the year before, at a time when only 2,400 people lived in the town and 1,300 students were enrolled in the college. The following four years saw a substantial increase in ridership, culminating in 403,460 riders in the 1906-7 fiscal year-more than doubling 1902 passenger levels (see table).

The level of heavy and sustained ridership created significant overcrowding problems for the A\&C. When the railroad had begun operations in 1891, eleven trains per day carried the student population of 425 . The level of service had doubled to 22 trains per day by 1897, with a student population of $547 .{ }^{13} \mathrm{At}$ that level of service, as photographic evidence demonstrates, passengers packed the cars by occupying all of the seats and standing in the aisles, on the outside platforms, and on the stairs. ${ }^{14}$ The overcrowded conditions only worsened as ISC's enrollment neared 1,300 students by 1902 . To try to meet the needs of its community, that September the A\&C expanded its timetable to 34 trains per day on roughly a half-hourly basis from 6:40 a.m. to 10:30 p.m. ${ }^{15}$

Even at 34 trains per day, the service could not keep pace with passenger demand. The A\&C had only two stations: one

12. Schilletter, "First 100 Years," 66. Not all of President Storms's correspondents on the issue of the Greek system supported its adoption. See, for example, letter dated 11/25/1907 in folder 4/10, box 4, RS 2/6, Albert Boynton Storms Papers, Special Collections, ISU Library.

13. ISC Student, $7 / 28 / 1897$.

14. Contemporaries noted that when the cars arrived from Des Moines in 1891 they were not equipped with strap-hangers for standing passengers. The A\&C quickly rectified that glaring error by installing straps in all of the cars. Meades, Squaw and Skunk, 142.

15. Ames Intelligencer, 10/2/1902. The timecard took effect on September 14, 1902. 


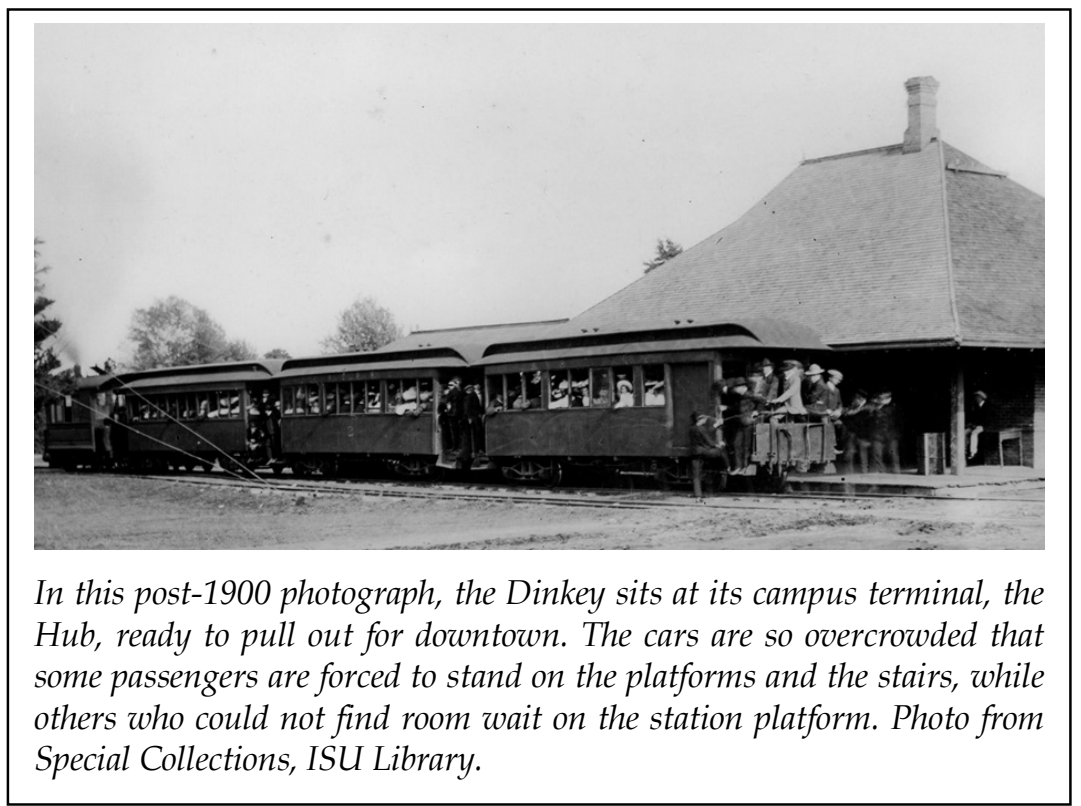

at the Hub on campus, and the second at its shed, or "round house," at the opposite end of its two-mile route at the east end of downtown. In 1896 the college had decided to build an unsheltered platform at the rear of the Farm House on campus, but the princely sum of five dollars that the college board of trustees committed to the project suggests that it was not a grand structure. ${ }^{16}$ At all other points along the route, passengers stood at street corners in whatever weather awaited them. The Intelligencer captured this frustrating situation for posterity, reporting that, on the first day of classes in the fall term of 1906, one frustrated student could do nothing but watch as the overcrowded Dinkey prepared to roll out for the college with no room for him. The student turned to Conductor Hank Wilkinson and asked, "Say, Hank, did you ever try putting on enough cars to haul half the crowd?" 17

16. The ISC Board of Trustees had ordered its construction in 1896, provided that the platform cost no more than five dollars. Minutes, ISC Board of Trustees, Book E, August 1894-July 1898, 5/15/1896, pp. 236-37; ISC Student, 4/13/1904.

17. Ames Intelligencer, 8/30/1906. 
The increase in the number of passenger trains conflicted with ISC's demands on the A\&C for freight service. Over the five years from 1902 to 1907, the Dinkey hauled the building materials for at least five new barns and agricultural research buildings and three faculty cottages. ${ }^{18}$ In addition, the A\&C hauled the freight needed to build all of the new major structures on campus: Central Hall (1904-1907, now Beardshear Hall), East Hall (1904-1907), Alumni Hall (1904-1907), Engineering Hall (19011903, now Marston Hall), and the new Agricultural Hall (19061909, now Curtiss Hall). These last five buildings alone cost over $\$ 1,007,000$, nearly three times what the entire college had been valued at in $1891 .{ }^{19}$ Hauling freight accounted for over 24 percent of the A\&C's total income from 1902 to 1907. It was common for many small rail lines to move freight traffic at night after passenger service had ceased, but the $A \& C$ also moved freight during the day. 20

Blending increased campus construction needs with expanding passenger timetables on a single rail line was an unenviable task. In the effort to meet the challenge of juggling passenger and freight traffic, the $A \& C$ found it difficult to remove empty freight cars in a timely manner; some sat empty on campus for extended periods, much to the frustration of the ISC board of trustees. ${ }^{21}$ In spite of the money the A\&C spent maintaining its track in these years, and even though the company almost

18. H. Summerfield Day, "The Iowa State University Campus and its Buildings, 1859-1979" (unpublished internal document, Ames, 1980), 480, Special Collections, ISU Library (also accessible at www.add.lib.iastate.edu/spcl/exhibits/150/campus.html).

19. Ibid., 159-62, 171-74, 215-16, 224-25, 341. In 1891 the total value of the college was estimated at $\$ 355,000$. Iowa State College of Agricultural and Mechanic Arts, Catalog, 1891 (Ames, 1891), 11.

20. For example, in 1901 Conductor Hank Wilkinson and Engineer Frank Lange were hauling an empty boxcar from campus on a June afternoon. Lange was riding the brake wheel on top of the boxcar. As the Dinkey moved down the city streets he was caught by a telephone wire, thrown off the back of the boxcar, and suffered severe injuries. Ames Times, 7/4/1901. In 1907 pedestrians walking to campus along the $\mathrm{A} \& \mathrm{C}$ embankment one afternoon were forced off the tracks by a string of freight cars being pushed back to town by the Dinkey engine. Ames Intelligencer, 10/3/1907.

21. Minutes, ISC Board of Trustees, Book C, July 1903-January 1907, 9/29/1905, pp. 369-72. 
completely rebuilt its road in 1902, the number of delays and accidents increased as numbers of heavily laden freight cars stressed the 30-pound rails, which were not meant to withstand such weight. ${ }^{22}$ While contemporaries often made fun of the delays, critics warned that these "numerous little accidents are only the forerunner of something that may be more than funny." 23

The crowded cars, the lack of upgrades to the old, degraded equipment, the presence of so many freight cars used for campus construction, and the diminishing level of service led some contemporaries to assume that the A\&C was simply awash in profits. The Student, for example, proclaimed in March 1904 that, in spite of its shortcomings, the A\&C was the "best paying railroad in the United States." The same publication noted in February 1906 that the A\&C paid "the largest dividends in Iowa" to its shareholders. ${ }^{24}$ Both claims were untrue, but for some, seeing the full cars and deplorable conditions on the Motor Line, it was easiest to blame a greedy corporate board.

Contemporary comments on the condition of the A\&C obscured the fact that the company did work to maintain its physical plant. In fact, the company spent more than ever before between 1902 and 1907 to properly maintain its cars (see table), but the stress of such heavy, daily use was so great that the company found it difficult to keep its physical plant in a proper state of repair. The floors of the cars were muddy, the windows were dirty, and hot cinders from the engine flew through the open windows of the passenger cars. ${ }^{25}$ In May 1903 a flange came off a wheel of a passenger car, driving it off the tracks. ${ }^{26}$

22. For reports of derailments on the Motor Line, see, for example, ISC Student, 1/27/1904, 3/5/1904, 3/16/1904, 4/13/1904. In 1906, after another widely covered derailment, Engineer Stull of the A\&C told the Intelligencer, "I can't understand why it would leave the track with such a light load when we have been hauling so many heavily loaded trains over the road lately." Ames Intelligencer, 9/20/1906.

23. ISC Student, 3/5/1904.

24. Ibid., 3/5/1904, 2/24/1906.

25. Ibid., 3/5/1904.

26. The mandated maximum speed of $8 \mathrm{mph}$ while steaming across campus or in town probably prevented many injuries when accidents and derailments happened like the one that occurred on May 27, 1903. ISC Student, 5/28/1903. 
TABLE

AMES \& COLLEGE RAILWAY OPERATIONS SUMMARY, 1901-1907

\begin{tabular}{lrrrrrr} 
& $1901-2$ & $1902-3$ & $1903-4$ & $1904-5$ & $1905-6$ & $1906-7$ \\
\cline { 2 - 7 } Income & & & & & & \\
$\quad$ Passenger & 5,824 & 8,878 & 10,754 & 12,066 & 13,835 & 16,542 \\
Freight & 3,300 & 2,085 & 3,928 & 5,574 & 4,549 & 3,871 \\
$\quad$ Other & - & 471 & - & 799 & - & 17 \\
Gross Income & 9,124 & 11,434 & 14,682 & 18,439 & 18,384 & 20,430 \\
Expenses & & & & & & \\
$\quad$ Repairs & 2,169 & 2,365 & 2,076 & 5,562 & 1,558 & 1,230 \\
Coal & 1,185 & 1,712 & 1,802 & 2,304 & 2,109 & 2,876 \\
Equipment & 512 & 1,490 & 1,353 & 754 & 1,704 & 556 \\
$\quad$ Salaries & 1,805 & 2,645 & 3,031 & 3,128 & 3,510 & 3,527 \\
Other & 677 & 1,442 & 1,617 & 1,724 & 1,829 & 317 \\
Total Expenses & 6,348 & 9,654 & 9,879 & 13,472 & 10,710 & 8,506 \\
Net Income & 2,776 & 1,780 & 4,803 & 4,967 & 7,674 & 11,924 \\
& & & & & & \\
Passengers & 116,483 & 177,560 & 215,070 & 241,324 & 276,669 & 403,460 \\
No. of Students & 1,064 & 1,272 & 1,271 & 1,412 & 1,353 & 1,363 \\
$\quad$ at ISC & & & & & & \\
\end{tabular}

Source: Annual Reports of the Railroad Commission for the State of Iowa.

As the tires on the cars wore away and could not be replaced, flat spots eventually developed on the wheels themselves that only added to the discomfort passengers felt as the train rumbled its way across the Squaw valley. ${ }^{27}$

The increased burden of heavy freight traffic meant that the A \& $C$ also had trouble maintaining its roadbed, rails, and ties. The 1891 contract with the college stipulated that the A\&C would keep its right-of-way clear of grass and weeds that could, at certain times of the year, pose a serious fire hazard either from hot cinders flying from the Dinkey's smoke funnel or from hot clinkers falling through gaps in the engine's firebox. As early as 1895 the college trustees had chastised the little railroad for failing to keep the right-of-way clear of weeds and grass. ${ }^{28}$ The growth of vegetation on the roadway was still a problem nine years later; in the autumn and winter of 1903-4, the "shower of sparks" cast from the engine started several serious brush fires. ${ }^{29}$

27. Ames Times, 9/12/1907.

28. Minutes, ISC Board of Trustees, Book E, Aug. 1894-July 1898, 7/17/1895, p. 121.

29. ISC Student, 3/16/1904. 
Increased stress on the Dinkey to keep to its expanded timetable led to employee carelessness, and overcrowding sometimes resulted in dangerous, even life-threatening incidents. Employee carelessness resulted in a serious accident in January 1896, when the train ran over five-year-old Davy Allen, resulting in the amputation of the lower portion of his right leg and a lawsuit that ended in a substantial judgment against the company. ${ }^{30}$ Still, the A \& C did not make significant changes to its safety procedures, and contemporaries took note of seeming employee carelessness with the Motor Line's equipment. In 1904, for example, one of the three passenger cars had to be taken off line and repaired because it had come into "violent contact with a freight car." A more dangerous incident occurred in July 1906 when one of the steam dummy engines "without engineer or fireman . . . ran away going at a furious gait." The engine ran the five-block length of Story Street, right through the heart of town, and would have run headlong into a Chicago \& North Western (C\&NW) freight train had not the C\&NW employee in the control tower thrown a derailer switch that "half buried" the A\&C's runaway train in a ditch. ${ }^{31}$

The overcrowded conditions on the Motor Line also resulted in serious accidents. In the late nineteenth and early twentieth centuries it was not uncommon for passengers to leap up on the platforms of slowly moving trains, either in the hope of riding them for brief distances or to avoid waiting for another trainor just to avoid paying the fare. ${ }^{32}$ Perhaps because contractual obligations with the city and the college restricted the Dinkey to a maximum speed of 8 miles per hour on city streets and on college grounds, some students, townspeople, and college faculty would leap on the rear platform of the cars as the train steamed

30. Ames Times, 1/30/1896; Ames Intelligencer, 1/30/1896; Supreme Court, State of Iowa, Allen v. Ames and College Railway, 106 Iowa, 602, 76N.W. 848, 10/26/1898, pp. 1-86. For the A\&C's lack of a safety manual of any kind in 1896, see pp. 7-9.

31. ISC Student, 3/5/1904; Ames Intelligencer, 7/5/1906.

32. One notable local example of this kind of behavior occurred after ISC allowed a Greek system to recolonize in 1904, after being banned in 1891. One of the new local fraternities was the "train-bumming brotherhood, Quo Vadis-abolished some years later after several accidents and one death had resulted from the qualifying activity of illicit travel." Ross, History of Iowa State, 247. 


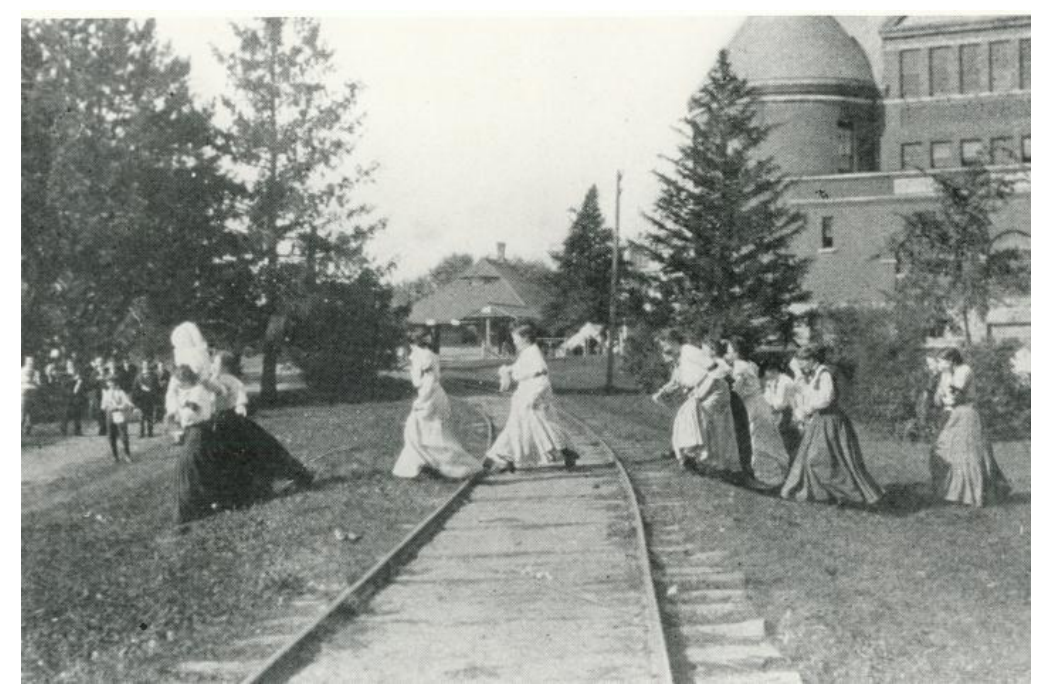

A group of women hustle across the Motor Line's embankment and tracks ahead of the oncoming train in this 1904 photo. By regulation, the Dinkey's speed was limited to 8 miles per hour through town and across campus, but with so many people on campus after 1902, scenes such as this were not uncommon, giving President Albert Storms some anxious moments. Photo from Farwell T. Brown Photographic Archive, Ames Public Library.

slowly past. Of course, leaping on the platform of a moving train is a tricky enterprise in the best of times, but on rainy, snowy, or icy days it could be extremely dangerous. ${ }^{33}$

One newsworthy accident that resulted from this behavior occurred on April 20, 1903, when Frank French, associate professor of electrical engineering, slipped while trying to board the Motor as the train "was moving at full speed." Newspapers across the state noted that French went tumbling, broke four ribs, and suffered other internal injuries that, fortunately, were not life threatening. Another serious accident on the Dinkey line that received similar statewide attention came on January 19, 1905, when a popular, well-known senior student, Ralph Collette

33. Ames City Ordinance \#94, which established the Ames Street Railway (before the investors changed the name to the Ames \& College Railway), stated that a strict speed limit of $8 \mathrm{mph}$ was allowed on city streets. City of Ames, Council Proceedings, 1880-1891, book 1, part 2, frontispiece. 
from Ida Grove, fell under the platform of the rearmost passenger car as he tried to board the moving train as it passed by Agricultural Hall. No bones were broken, but the story spread all the way up to northern Iowa, where the tiny Buffalo Center Tribune reported that Collette had recovered from his injuries and returned to campus by the end of February. ${ }^{34}$ Clearly, the A\&C needed to address safety issues, but it could not afford to do so.

FOR THE SHAREHOLDERS and officers of the A\&C, the new century seemed to offer the promise of continued prosperity for their proud local franchise. Relations between the A\&C and ISC appeared to be stronger than ever. ${ }^{35}$ To anyone familiar with the way the railroad conducted its operations, however, the seeds of future difficulties were evident. While prosperous in its dilapidated state, the Motor Line could not afford to make the $\$ 80,000$ worth of improvements necessary to keep pace with modern technology and safety protocols. So, while the A\&C was a solvent enterprise, its prosperity was insufficient to meet the company's needs.

The Motor Line's insufficient profitability resulted, in part, from its relationship with its chief customer, Iowa State College. From the A\&C's inception in 1891, the college's board of trustees had mandated that no one-way ride would ever cost more than 5 cents. The A\&C began as a railway of the "third class," which allowed it to charge 3 cents per mile carried for each passenger. Thus, it could have charged 6 cents for a trip to the college. In the early days, the loss of one penny per rider did not seem to make much difference. But when the $\mathrm{A} \& \mathrm{C}$ became a railway of the "second class" in 1901, state railroad regulations allowed it to charge 4 cents per mile for passenger traffic, or 8 cents to or from downtown. Thus, it could then have charged 16 cents for a round-trip fare (instead of 10 cents), 60 percent more than it was charging. ISC's board of trustees, however, would not hear of

34. ISC Student, 4/18/1903; Dubuque Telegraph Herald, 4/20/1903; Des Moines Capital, 1/20/1905; Sioux County Herald, 1/25/1905; Cedar Falls Gazette, 1/27/ 1905; Buffalo Center Tribune, 2/27/1905.

35. For example, the Motor Line was at the table as an equal partner when the college discussed transportation matters with the C\&NW in 1900. Minutes, ISC Board of Trustees, Book F, July 1898-July 1903, 5/25/1900, p. 210. 
raising the fare, and as late as 1905 the board was still demanding that a one-way fare would never cost more than 5 cents. ${ }^{36}$

While some of the railway's insufficient profitability may be blamed on the college, other factors contributing to its lack of profitability in these years were its own doing. Contemporaries noted that the A\&C was more concerned with "neighborliness" and being part of the community than with increasing the railway's profitability. ${ }^{37}$ The board of directors and Marcellus K. Smith, the A\&C's general manager, seem to have viewed the train first and foremost as a servant of the community. ${ }^{38}$ For example, the community certainly appreciated the A\&C's efforts when, after four ISC students died as a result of an outbreak of typhoid fever in October and November 1900, the Dinkey laid on special trains to and from the funeral services on campus free of charge. ${ }^{39}$

This use of the Dinkey as a community servant was not an isolated incident but, rather, a pattern of behavior. The Dinkey was dressed overall with ISC banners for Excursion Days, when thousands of Iowans visited campus, and for homecoming weekends. After ISC football victories, the Motor Line allowed students to "borrow" the flat car to carry lumber to campus for victory bonfires, and in May 1902 "[Conductor Henry Wilkinson's] five cent conveyance [was] no less a feature of importance

36. William H. Thompson, Transportation in Iowa: A Historical Summary (Ames, 1989), 113; Daily Iowa Capitol, 1/7/1901. For the ISC Board of Trustees' demand that the charge never rise above 5 cents for a one-way fare, see the A\& \& 's initial agreement with the college in 1891 in Minutes, ISC Board of Trustees, Book D, May 1888-May 1894, 1/9/1891, pp. 159-60. In 1905 the trustees demanded that a one-way fare still never exceed 5 cents. Minutes, ISC Board of Trustees, Book C, July 1903-January 1907, 9/29/1905, pp. 369-72.

37. Meades, Squaw and Skunk, 143. According to the Ames Intelligencer, 4/23/1908, the Dinkey's timetable "correspond[ed] to the opening and closing of public and private affairs," rather than having those events correspond to the A\&C's needs.

38. It was not unusual for street railways in smaller Iowa towns to operate this way. For example, in 1886, when local Red Oak businessman Marcus Bonham acquired the horse-and-mule-drawn street railway in the town, "he made no attempt to run [the car] on schedule, except that he regularly made the trains." Merritt, History of Montgomery County, 293.

39. President Beardshear appreciated the Motor Line's efforts and asked the trustees to give the company their thanks, as well. President's Report to the Trustees, 12/11/1900, p. 9, folder 2/4, box 2, RS 2/5, Beardshear Papers. 
regarding the yellow and white" banners and decorations for May Day. 40

General Manager Smith also served his community by assisting the local school district. In spite of the growth in the community to the south and west of the ISC campus, the Ames school board understood that the district could not sustain another school in western Ames because there was only an average of seven children per class beneath high school. Thus, the children had to be brought to schools in town, so the district worked out a relationship with the $A \& C$ so that the 75 children who lived in the Fourth Ward (the area to the south and west of the college) would be able to ride the Dinkey to school, to home and back for lunch, and then home for the day, for a total of \$50 per month, rather than the $\$ 300$ per month that the Motor Line would have received had the company required the students, their parents, or the district to pay the full fare. ${ }^{41}$ More often than not, it seems that considerations of community good outweighed the good of the company. The combined effect of these business practices before 1902 ensured that the A\&C always had two things: the love of the community and a modest net income.

But perhaps the thing that most contributed to the A\&C's inability to realize the income fairly due to the company was its repeated failure to collect fares from every passenger. When passengers occupied all of the seats and stood in the aisles, on the platforms, and on the stairs, collecting fares from those who jumped or somehow squeezed on board when the train stopped

40. Meades, Squaw and Skunk, 143; Ames Intelligencer, 5/8/1902; H. E. Davis, in folder 2, box 24, 13/5/15, Louis Pammel Papers, Special Collections, ISU Library. Another factor that cut into the A\&C's profits was the laying on of numerous "Special Motors," which were usually late-night trains that carried passengers off the regular schedule. There were so many of these "specials" that it is impossible to track them all, let alone know what kind of income they realized. In November 1894, for example, the railroad ran Special Motors every night for a week to allow townspeople and students to attend 13 evening programs at the college. ISC Student, 11/6/1894. In the Intelligencer's December 1907 retrospective on the Dinkey, the paper noted that "late entertainments on the campus or in town always found the dinky waiting at the close." Ames Intelligencer, 12/5/1907.

41. The 1903 report to the State Board of Educational Examiners noted that Dinkey conductor Hank Wilkinson kept strict rules to "govern the behavior of the pupils on the cars." Biennial Report of the Superintendent of Public Instruction for the State of Iowa, vol. 31 [1901-1903] (Des Moines, 1903), 204. 
was a difficult proposition. Standard procedure seems to have been to let passengers ride part of the way for free. For example, in 1907 the Intelligencer noted, "You could jump on at Duff street and ride to the crossing or get on at the barns and ride to the Central building on campus without paying the fare." 42

In spite of the Dinkey's faults and the ever increasing deluge of complaints from its customers, the Motor Line's directors were not idle after 1902 . The company worked diligently to enhance its enterprise as best it could. In the autumn of 1902, the A\&C increased the number of passenger trains from 22 to 34 per day and engaged new employees to run the second engine. Since its inception in 1891, the Motor Line had always gotten by with one engineer, one conductor, one stationmaster, and the occasional "track man." In 1902, when the A\& C added a second engineer and conductor, its employees were the lowest paid in the state, even lower than the notoriously underpaid employees of the Iowa Central Railroad. ${ }^{43}$ Yet, in spite of less than ideal working conditions and low pay, the $A \& C$ never suffered the labor problems associated with larger carriers, and the men who worked on the little railroad tended to stay with the company for a long time. Many of the Motor Line's employees were from Ames, so proximity to home and family might have helped make up for a low salary. In addition, the Ames newspapers turned these employees into local celebrities, which possibly helped retention as well.

The effect of these local employees and their relationships with students and townspeople helped the $A \& C$ retain some goodwill with the community during the company's declining years from 1902 to 1907. The Ames Intelligencer noted that, because of the "little courtesies" that General Manager M. K. Smith and the employees tendered to the passengers, the Dinkey be-

\section{Ames Intelligencer, $12 / 7 / 1907$.}

43. In 1907, for example, the A\&C paid a total of $\$ 1,412$, or $\$ 1.97$ per day, to its two conductors for their annual salary. By comparison, the Iowa Central paid its conductors $\$ 3.49$ per day. That same year, the $A \& C$ paid its two engineers a total of $\$ 1,539$ for their annual salary, or $\$ 2.15$ per day, while the Iowa Central paid its engineers $\$ 4.28$ per day. Thirtieth Annual Report of the Board of Railroad Commissioners for the State of Iowa for the Year Ending June 30, 1907 (Des Moines, 1908), 91-92; Don Hofsommer, The Hook and Eye: A History of the Iowa Central Railroad (Minneapolis, 2005), 104-5. 
came a "home like vehicle." "You could not help but boost the dinky," the Intelligencer continued, "because M. K. Smith gave you an interest in the concern." 44 Ames native Frank Lange, for example, made a great number of friends during the decade he spent working as an engineer on the Motor Line before he retired in 1907.45 Lange lived the rest of his life in Ames, and even in the mid-1950s he was still remembered for his time on the Dinkey. ${ }^{46}$

But by far the most significant of these long-serving employees was Henry P. "Hank" Wilkinson. Wilkinson had settled in Ames to raise a family and came to work for the A\&C in 1892 after working for the Chicago \& North Western Railroad for a number of years, and he never left. Hank was a tall, powerfully built man who was quick to laugh and made friends easily among students and townspeople. He possessed the kind of self-confidence that quickly put those around him at ease. Contemporaries thought Hank could solve any problem and handle any emergency on the Motor Line. Throughout the 15 years that he worked for the $A \& C$, both student and city newspapers chronicled his exploits great and small and were not above poking fun at his expense. For example, the ISC Student noted that one May afternoon Hank found himself engaged in telling one of his jokes on the station platform, but before he could finish, the engineer opened the throttle and the Dinkey pulled out of the Hub headed for downtown. "The jolly conductor discovered his predicament and started to follow the car at a pace that would put to shame any of our 'sprinters,'" the newspaper explained, but "the timers failed to get the correct time and the best record of the season was therefore lost." In 1903 Wilkinson was mentioned prominently in the report to the State Board of Educational Examiners for his work in seeing to the safety and proper behavior of the schoolchildren who rode the Dinkey on a daily basis. In 1905 the ISC yearbook penned a laudatory poem in his honor. Even in the dark days after the sale of the A\&C, when contemporaries feared that the little train would fall apart from

44. Ames Intelligencer, 12/5/1907.

45. Upon his departure from the Motor Line, Lange told the Intelligencer that he "rather [dis]liked leaving the old dinkey" because he had made so many friends. Ames Intelligencer, 1/24/1907.

46. Meades, Squaw and Skunk, 140-43. 
overuse, the Intelligencer reminded its readers, "Pin your faith to Hank because the cars won't go up as long as he is on board to hold them down." 47

The A\&C did work to upgrade its service within the bounds of what it could afford. One way it attempted to improve its service was by taking advantage of new technologies. In January 1902, for example, C. George Greene, an inventor from Cedar Rapids, contracted with the Motor Line to install his new electrical signal system meant to inform railroads of open switches and broken rails, the latter of which was not an uncommon occurrence on the Motor Line. ${ }^{48}$ More significantly, in the summer of 1902, the A\&C undertook a complete reconstruction of the line. The company took down the original bridges across Squaw Creek and the back channel and contracted with the C\&NW to build a new 160-foot-long wooden bridge over Squaw Creek. ${ }^{49}$ The entire line was regraveled, and more than 1,000 new ties were laid at an estimated cost of $\$ 2,500.50$ Upgrading the rails themselves came in 1904. The Ames Times reported in November that the A\&C had been able to upgrade to 60-pound rails "on about half" of the line and that the road would upgrade the remainder "as soon as practicable." 51

In spite of what improvements to its physical plant the A\&C could afford, the directors knew that to ensure the continued ex-

47. ISC Student, 5/15/1900; Biennial Report of the Superintendent of Public Instruction for the State of Iowa, vol. 31 [1901/1903] (Des Moines, 1903), 204; ISC Bomb, 1905, p. 168; Ames Intelligencer, 10/24/1906. Wilkinson ended his service to the A\&C as manager of operations. Ames Intelligencer, 2/7/1907. In spite of Ames citizens' "faith in Hank," one of the Dinkey engines did finally break down from overuse. As the Intelligencer reported, the engine broke down and "went to pieces like the one-hoss shay. It has seen its last days of travel." Ames Intelligencer, 8/15/ 1907.

48. Cedar Rapids Evening Gazette, 1/8/1902. See also bundle 17, box 1, series 1, MSC0225, C. G. Greene Papers, Special Collections, University of Iowa Libraries, Iowa City.

49. The editors of the ISC Student claimed that the bridges' poor condition and the fear they would be swept away in a flood led the A\&C's directors to rebuild them and repair the entire line. ISC Student, 3/5/1904.

50. Cedar Rapids Evening Gazette, 8/12/1902.

51. Ames Times, 11/24/1904. The paper also noted that travel on the new rails was greatly enhanced and that the difference between the old and new rails was "felt decidedly." 
istence of their franchise they would need to electrify their line. Just as the A\&C had relied on ISC students to help found the railway in 1891, the directors turned to students again and used their academic work to provide the railroad with viable options for upgrading and electrifying the line. In 1904 two groups of senior students coauthored theses that studied the possibility of converting the A\&C to electric power. Like the work of James Bramhall and Charles Davidson 14 years earlier, the theses were thoughtful, well meaning, and well researched. ${ }^{52}$ Five students worked on these two senior theses: Arthur Buckley, Harold Scranton, and Earl Shreve were electrical engineers; the other two, Frank Brown and Lester Morris, were civil engineers.

Buckley, Scranton, and Shreve's thesis, titled "Design and Specifications for Changing the Present A.\&C.R.R. from Steam to an Electric Road," put forward a complete redesign of the $A \& C$. The students spent a good deal of time discussing the issues with A\&C General Manager M. K. Smith, who provided them with a substantial amount of accurate information on the railroad. The students' work was straightforward and practical. It argued for a complete rebuilding of the line from its sheds at the east end of Onondaga Street to campus, including a new steel bridge across Squaw Creek. The students wanted to run rails down 5th Street, across the C\&NW mainline, across the Squaw, and up the grade to the college. But rather than coming through the heart of the college farm as the line currently did, it would swing out to the north before it got to the farm and then proceed to the western edge of campus before turning back on itself - in essence, creating a loop around campus. The students proposed to run trains every ten minutes so that there would always be one car coming to campus and another coming from campus. They argued that the entire loop could be completed in about 20 minutes. They further suggested that passenger service run from 6:30 a.m. to 11:00 p.m. daily, and they thought that one

52. J. A. Bramhall and C. D. Davidson, "Electrical Railroad between Ames and the College" (senior thesis, Iowa Agricultural College, 1890). In 1898 a group of ISC engineering students had worked up a plan for electrifying the line, but nothing came of their efforts, W. J. Devine, W. H. Grover, and J. C. Kyle, "Specifications and Estimates for Complete Electrical Equipment of Ames and College Railway” (senior thesis, ISC, 1898). 
of the steam dummy engines would need to be retained for the delivery of freight after passenger service had halted for the day. ${ }^{53}$

Brown and Morris, the civil engineering students, in their 1904 thesis, "The Ames and College Belt Line," concentrated their analysis on the requirements for preparing, building up, and grading the new roadbed that the electrical engineering students proposed. Like their electrical engineering colleagues, Brown and Morris found the officers of the A\&C helpful in their research. They noted the "dilapidated condition of the present rolling stock" and the unsatisfactory state of the current roadbed. They argued that running a single-track belt line around the fringe of campus, rather than merely upgrading and electrifying the current route, would be the best solution to ISC's transportation problems. ${ }^{54}$

While the railroad worked with ISC students to develop plans, it also entered into negotiations with the City of Ames to provide electric power for the enterprise. In January 1905 the A\&C's board of directors had detailed a committee of three to work with Superintendent F. W. Linebaugh of the Ames Power Plant to negotiate a relationship between the public utility and the railroad for the purchase of electric power. The Intelligencer and the Times could barely contain their enthusiasm for the project, the latter noting that "the smoke and shriek of the dinky will be a thing of the past." 55 President Storms was caught up enough in the excitement to tell the governor in the college's biennial report that "the substitution of electric motor power for the locomotive power of the Ames \& College Ry. is not a remote probability, [it is] a probability which is becoming more and more likely of being an accomplished fact." 56

The optimism expressed by President Storms and the local newspapers proved misplaced. No records of the meetings between A\&C managers or directors and Superintendent Line-

53. Arthur R. Buckley, Harold L. Scranton, and Earl O. Shreve, “Design and Specifications for Changing the Present A.\&C.R.R. from Steam to an Electric Road" (senior thesis, ISC, 1904).

54. Frank Brown and Lester Morris, "The Ames and College Belt Line" (senior thesis, ISC, 1904), 1-7.

55. Ames Times, 1/12/1905; Ames Intelligencer, 1/12/1905.

56. Twenty-first Biennial Report of the Iowa State College of Agriculture and Mechanic Arts, 1903-1905 (Des Moines, 1906), 48. 
baugh of the Ames Power Plant survive, but city council minutes demonstrate that the Ames power plant had overreached capacity by 1904 and was overloaded for roughly three hours each evening. ${ }^{57}$ Although the city expanded its power plant in late 1905, it is doubtful, given the increasing demand for electricity in the town, that the $A \& C$ could have drawn power from city electric services. ${ }^{58}$

With the community power plant unable to provide electricity, the A\&C tried to solve the problem on its own, but that attempt led to a dead end when the directors found that they could not raise sufficient capital to fund the enterprise. Even if the student estimates were low, the costs that the students provided for the project were prohibitive. When they calculated the cost of rebuilding the line using electricity instead of steam, the grand total came to $\$ 79,772$ (roughly $\$ 2.1$ million in 2015 dollars).

Raising that much capital probably seemed impossible to the railroad's directors and friends, who included both Parley Sheldon and Wallace Greeley, owners of the two banks in town. For the 1902-3 fiscal year, the A\&C realized only $\$ 1,780$ in net income. Even if the company sold all of the engines and rolling stock it owned, the profit generated would not have been enough collateral for any bank in Ames to even consider lending nearly $\$ 80,000$ - assuming the local banks even had access to that kind of cash. 59

Thus, by 1905 the A\&C faced a dilemma. Although the company was profitable, it was rapidly outliving its usefulness. The little railroad had no choice but to operate with the outmoded and outdated equipment that it owned, which fell into even greater disrepair. Breakdowns, overcrowding, and derailments became more common, and the Dinkey was forced to endure

57. City of Ames, Council Proceedings, 1900-1907, 11/7/1904, p. 294.

58. From 1901 to 1904 the demand for electric service in Ames had nearly doubled and there were petitions for more customers. In September 1905 the city allotted $\$ 4,440$ to expand the plant, which was not brought on line until the spring of 1906. City of Ames, Council Proceedings, 1900-1907, 3/6/1905, p. 321; $7 / 31 / 1905$, p. $375 ; 8 / 7 / 1905$, p. $380 ; 9 / 7 / 1905$, p. $395 ; 10 / 2 / 1905$, p. 399; 12/4/1905, p. 413; 2/5/1906, p. 427.

59. When the A\&C sold out to the Newton \& Northwestern Railway, it received only $\$ 40,000$ for the entire company, barely half of what the student studies demonstrated was needed to electrify the line. 


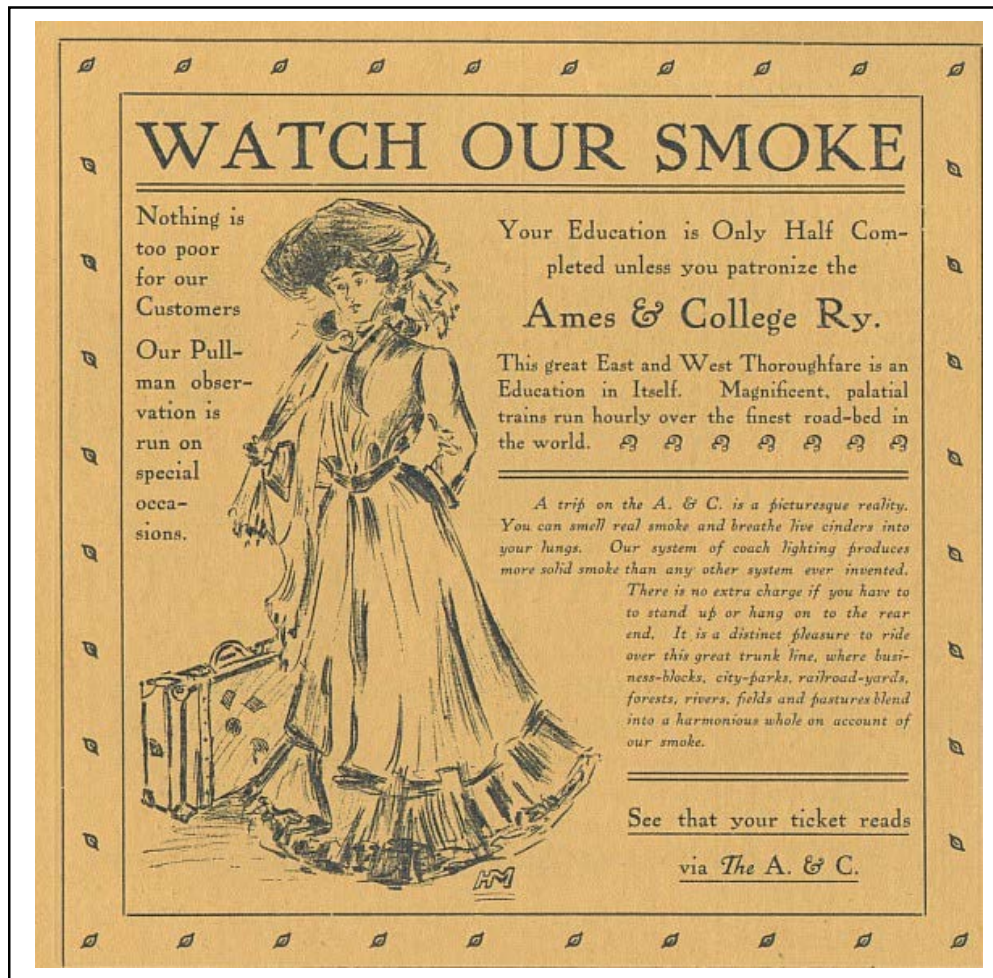

This satirical faux advertisement, from the 1906 ISC yearbook, The Bomb, is a good example of how the student community viewed the train by that time. Many of the frustrations the students felt about the Dinkey, including smoke, cinders, and overcrowding, are satirized in the ad.

increasing layers of abuse as community members vented their collective frustrations on the little train. Faux advertisements for the Dinkey and even an obituary for the little train graced the yearbook's pages in the railroad's final year. For many people in the college and the city, the Dinkey, with its negative press, fading reputation, and dangerous operating conditions, had become a symbol for what was wrong with the community rather than what was right. Again and again, contemporaries offered up pleas to upgrade the service on the Motor Line "in the name of progress and common sense." 60 
REGARDLESS of community and student complaints and the company's attempts to improve its service as best it could, the ultimate arbiter of the $A \& C^{\prime}$ s relationship with the community was its principal customer: Iowa State College. The pressures on the college after the Main residence hall burned in August 1902 had become acute. ${ }^{61}$ In 1903, for example, the college found that it could house barely half of the young women who sought to enter ISC as students. Because trustee policy did not yet allow for young women to be housed off campus, many students were turned away from the "people's college." 62 Although ISC's enrollment leveled at about 1,400 by 1904, the college could still house only about 228 students.

This "housing crisis" led President Albert Storms and the trustees to try to find ways to solve the problem. The conditions in the boardinghouses and small businesses that sprang up on the southern fringe of the campus in the late 1890s were poor, and numbers could not keep pace with enrollment. Thus, the majority of students lived in town and commuted to campus on the Dinkey. By encouraging the construction of boardinghouses and allowing Greek Letter houses to colonize, the college alleviated some of its demand for housing. Understandably, the college's leaders became deeply concerned with the vehicle used to move students between their homes in town and the campus.

As the only reliable mass transit option serving the campus, the Motor Line was central to any discussion of campus replanning. What came from that replanning was a dramatic change in the very nature of the $A \& C^{\prime} s$ purpose vis-à-vis the college it served. Nineteenth-century educators had thought that the physical beauty of a campus was an integral part of the educational experience. The way groves of trees were oriented, where buildings were placed, and, in ISC's case, even where rail track was laid out had a didactic effect as well as a practical one. After President William Beardshear determined the route of the A\&C's

61. The burning of the Main left ISC with the following residence halls: the Creamery (50 male students), the East Boarding Cottage (30 male students), the West Boarding Cottage (60 male students), and Margaret Hall (88 female students). The trustees set a committee to study the possibility of renovating the two boarding cottages in 1904, but the committee found that repairing the structures would not be cost effective. Schilletter, "First 100 Years," 55, 66.

62. Schilletter, "First 100 Years," 66. 
rails across campus in the summer of 1891, visitors who would come to ISC via rail were given the grandest possible introduction to the institution. ${ }^{63}$ Beardshear went on to lay out the buildings of his significant building program in what one observer considered "a pretentious way." 64 The Dinkey was an integral part of Beardshear's vision for ISC.

The grandeur of the campus Beardshear created left the impression he wished on many who experienced it, but within three years of his passing in 1902, forces aligned to significantly alter what he had created. By the spring of 1905, Beardshear's idea of the campus belonged to an earlier age, and it was clear to many college leaders that the overcrowded, single-track railway could not satisfy the needs of the existing campus, let alone the one the trustees and President Storms intended to build. The increasing number of accidents on the Motor Line, coupled with the increasing number of students walking on the railway's embankment, worried campus leaders and led them to propose repositioning the Dinkey's rails away from the campus's central core. ${ }^{65}$

At the March 1905 board of trustees meeting, Trustee William McElroy, who, in 1890, had served on the subcommittee that allowed the A\&C to come to campus, asked his fellow trustees to form a committee charged with investigating the relationship between ISC and the A\&C with "reference to each other and such changes in their relations and rights or in the location of the tracks of the said railway company as in the judgment of said committee should be made." 66

The trustees' committee met with the A\&C's directors several times during the late spring or summer of 1905. There are no records of what took place at those meetings, but it is clear that the trustees' committee considered it necessary to recast the relationship between the $\mathrm{A} \& \mathrm{C}$ and the college. Perhaps the most poignant example of how dramatically the relationship with the railroad had changed is that Professor Anson Marston, the col-

63. For a fuller discussion of this point, see Biggs, "Forging a Community," 223-25.

64. Velma Wallace-Rayness, Campus Sketches of Iowa State College (Ames, 1949), 14.

65. President's Report to the Trustees, 12/23/1904, folder 1/5, box 1, RS 2/6, Storms Papers.

66. Minutes, ISC Board of Trustees, Book C, July 1903-January 1907, 3/8/1905, p. 247. 
lege engineer, rather than anyone employed by the A\&C, spent a good deal of time in the summer of 1905 laying out and surveying a new route for the railroad. ${ }^{67}$ Marston's survey demonstrated that the college's needs had changed, and it no longer needed to provide such a grand introduction to campus. The new route was practical and safe. From the point where the proposed electric tram car cleared the college farm, Marston ran the rails north to the fringe of campus, where the electrified line would be less of a threat to pedestrians on campus. 68

In September 1905 McElroy's committee delivered its report. The committee asked the A\&C to adopt "electricity, gasoline or some other motive power not accompanied by smoke" and to rebuild the on-campus portion of its line to conform to Marston's survey. The committee also demanded that the company maintain its roadbed in "a proper and sightly manner" and that the A\&C keep the right-of-way clear of weeds and trash. The committee further recommended that the college continue to mandate that a fare between Ames and any point on campus never cost more than 5 cents. Last, and by no means least, the committee stated that it was "desirable that the changes herein recommended be made during the present year, in order that the grounds now occupied by railway tracks and depot may be placed in first-class condition before freezing weather." 69

By the winter of 1905-6, the A\&C's directors found themselves in possession of an organization at the end of its useful existence. Although the company was making more money than it ever had before, the trustees' committee had made it clear that the college no longer had any interest in continuing its relationship with a steam-powered railway, and the A\&C did not have the resources necessary to electrify its line. Consequently, the A \&C began to search for a buyer.

The Ames newspapers reported that two railroads entered into negotiations with the A\&C in the autumn of 1905. The first

67. Anson Marston had spent two-and-one-half years as a resident engineer on the Missouri Pacific Railroad before coming to ISC in 1892. Herbert Gilkey, Anson Marston: ISU's First Dean of Engineering (Ames, 1968), 13-14, 19, 91.

68. Minutes, ISC Board of Trustees, Book C, July 1903-January 1907, 9/29/1905, pp. 369-72.

69. Ibid. 
was a locally owned railroad known as the Central of Iowa. This was little more than a paper railroad owned by an Ames city councilman, Dr. John Snyder. The newspaper reported that he had the survey of a route and articles of incorporation, but no investors and not much money..$^{70}$ Nonetheless, Snyder pushed ahead. In March 1906 he asked the city council to grant his railroad the right to run an electric train down the streets of Ames. The council referred his request to a committee, and it was never considered again.

The second railroad with an interest in the A\&C that autumn was the Newton \& Northwestern Railway. The N\&NW had begun in 1893 as the Boone Valley Coal \& Railway Company, a freight service hauling coal in the Des Moines valley. Through a series of mergers, buyouts, and name changes the N\&NW owned a viable road between Newton and Rockwell City by 1904. Like the A\&C, the N\&NW made only enough profit to get by, and it needed to diversify its services and attract outside investors. ${ }^{71}$ In 1905 Homer Loring from Boston and a number of East Coast investors bought out the railroad, providing the much needed capital. ${ }^{72}$ The acquisition of the A\&C promised to add robust passenger traffic to the N\&NW's stable of services. In February 1906 the ISC Student reported that the A\&C had been sold to the N\&NW, which soon underwent another name change to the Fort Dodge, Des Moines \& Southern. The Intelligencer noted that the N\&NW purchased the A\&C for $\$ 40,000.73$

\section{Ames Intelligencer, 4/19/1906.}

71. The N\&NW's report to the railroad commission demonstrated that in fiscal year 1904-5 the railroad hauled 113,859 tons of bituminous coal, but generated only $\$ 9,532$ in net profit. Twenty-Eighth Annual Report of the Board of Railroad Commissioners of the State of Iowa for the Year Ending June 30, 1905 (Des Moines, 1905), 111, 116.

72. The influx of cash from the eastern investors greatly aided the N\&NW's bottom line. In fiscal year 1905-6 the railroad reported a net profit of $\$ 26,303$ to the railroad commissioners, and in fiscal year 1906-7 the railroad (still reporting as the N\&NW) reported a net profit of $\$ 44,528$. Twenty-ninth Annual Report of the Board of Railroad Commissioners of the State of Iowa for the Year Ending June 30, 1906 (Des Moines, 1906), 110; Thirtieth Annual Report of the Board of Railroad Commissioners of the State of Iowa for the Year Ending June 30, 1907 (Des Moines, 1907), 111.

73. ISC Student, 2/24/1906; Ames Intelligencer, 4/19/1906. The name officially changed on February 16, 1906. Frank Donovan, Iowa Railroads: The Essays of Frank P. Donovan, Jr., ed. H. Roger Grant (Iowa City, 2000), 76-77. 
The A\&C officially changed hands on May 1, 1906, when Operations Manager Hank Wilkinson handed over the keys to the office. ${ }^{74}$ The Dinkey continued to operate under new management while the FDDM\&S built its electrified road. The FDDM\&S made good on its promise, bringing in opulent 70foot interurban cars with mahogany woodwork, rich leather seats, and clerestory windows that brought light and fresh air into the cars. Ames citizens were favorably impressed, and railroad historian Frank Donovan Jr. referred to the cars as "the pride of central Iowa." 75 At about 10:00 p.m. on the evening of Friday, September 6, 1907, the Dinkey made its final passenger run from Ames to the campus and back. ${ }^{76}$ Electric interurban service began the next day. ${ }^{77}$ Thus, the "pride of central Iowa" replaced the "pride of the community."

BETWEEN 1902 and 1907 the Ames \& College Railway suffered an almost complete reversal of opinion among the people of the local Ames and ISC community. The little train that had done so much to unite and be an integral part of the community of Ames in the 1890s had, within 15 years, outlived its usefulness to that same community. An increasing number of breakdowns, accidents, and problems with overcrowding eroded the A\&C's ability to serve its customer base effectively. ${ }^{78}$ The little railroad did work to enhance its service in those years, but its efforts were not enough to be effective. The railroad's inability to raise sufficient capital to convert the line to electric power left it at the

74. Ames Intelligencer, 5/1/1906; Ames Times, 8/16/1906.

75. Donovan, Iowa Railroads, 77. For just a few of the instances of the local papers' reporting on the impressive nature of the FDDM\&S ownership, employees, and, especially, the new cars, see ISC Student, 9/9/1907, and Ames Intelligencer, 3/1/1906, 3/29/1906, 9/13/1906, and 10/25/1906.

76. ISC Student, 9/9/1907. The A\&C continued to operate under its original name until the end of the 1907-8 fiscal year, when it officially ceased to exist. Story County Recorder's Office, Miscellaneous Books, vol. 56, p. 41. Like the A \& C, the N\&NW continued to operate until the end of the 1907-8 fiscal year, when it too was subsumed by the FDDM\&S. Thirtieth Annual Report of the Board of Railroad Commissioners of the State of Iowa for the Year Ending June 30, 1907 (Des Moines, 1907), 234-41.

77. Ames Intelligencer, 9/12/1907.

78. ISC Alumnus 1 (April 1906), 139-40. 
mercy of its largest, and really only, customer: Iowa State College. When the college's trustees and President Storms decided that they needed the train to serve as a transportation system rather than as the vehicle to introduce the campus to its visitors in a grand manner, they made demands on the $A \& C$ that the company could not afford, which left sale as the only option.

Yet, amid all of the abuse heaped on the Dinkey by contemporaries, and even as the A\&C lumbered towards its end in the autumn of 1907, a strand of Dinkey nostalgia developed. One of the earliest threads of that nostalgia can be traced to August 1907, when the Intelligencer ran a story telling its readers that they would now need to buy watches, as they would no longer be able to tell the time of day by the Dinkey's steam whistles, for years the surest clock in the community because, of course, the train had always been on time. ${ }^{79}$ Certainly, that claim was patently untrue, but a segment of the Ames community wished to believe it was true. The Dinkey's final passenger run in 1907 was a moment for the Times to wax nostalgic about the little train. The paper noted that many of the passengers that September evening "were loath to give up the old 'dinky' which had grown nearer and dearer to them throughout the years." 80

In the decades that followed the A\&C's demise, the nostalgia around the Dinkey gave way to myth, which, in turn, gave the little train a legendary status. The memory of the Dinkey has lived longer and become more powerful than any of the historical facts surrounding its operations. Even before Ames's centennial in 1964, collective community memory had made the Dinkey the most recognizable symbol of the city's history. ${ }^{81}$ The Dinkey's place in the town's mythology became even more secure during the city's sesquicentennial celebration in 2014. A public mural featuring the Dinkey on the wall of a local business, stainedglass windows in the Gold Star Hall of the Iowa State University Memorial Union, terra cotta bas-reliefs on downtown Ames kiosks, public exhibits and lectures by the Ames Historical Society, printed acrylic Dinkey banners hanging from downtown

79. Ames Intelligencer, 8/9/1907.

80. Ames Times, 9/12/1907.

81. Meades, Squaw and Skunk, 36, 37, 86, 104, 140-43, 151. 


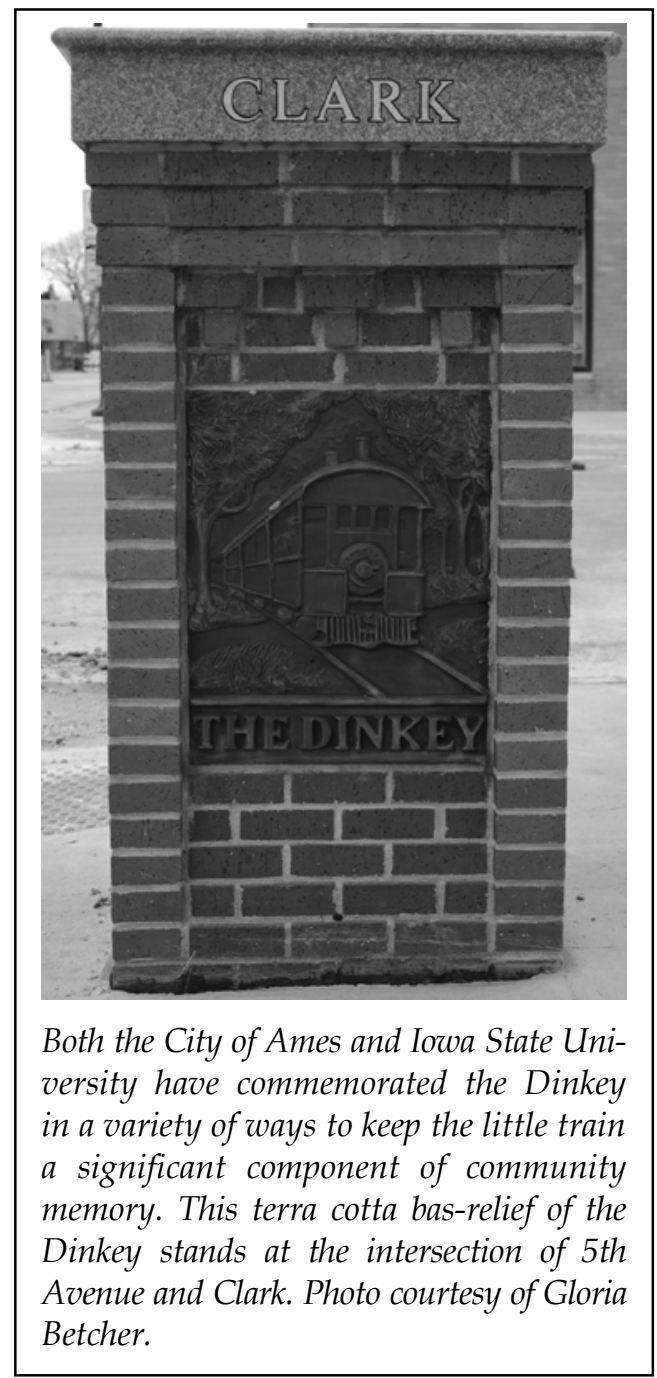

light poles, and even a craft-brewed wheat beer from a local micro-brewery named for the Dinkey all demonstrate how the Dinkey has been adapted and repurposed to remain an ever present, ever new, and ever significant part of the collective community memory of Ames and Iowa State University. 